\title{
Verne Marshall's Leadership of the No Foreign War Committee, 1940
}

Jusłus D. Doenecke

In the late 1930s and early 1940s, Verne Marshall of Cedar Rapids attained a statewide and subsequently a national reputation. He became known, through the newspaper he edited, the Cedar Rapids GaZeTte, as a crusader against corruption in state government. In 1936 his paper was awarded the Pulitzer award for "the most distinguished and meritorious public service among newspapers" for its crusade "against corruption and misgovernment in the state of Iowa." Nationally he was an explosive advocate of isolationism prior to American entry into World War II. He provoked criticism and controversy and was one of the most respected, hated, feared-and read-men in Iowa. His editorial crusades were many and varied. Verne Marshall, as one Iowa journalist during the forties pointed out, was a man of sudden and violent enthusiasms. And, as Professor Doenecke shows in the following article, the results of his crusades were not always what they might have been.-Ed.

WITHIN THREE AND A HALF months of the formation of the America First Committee, the establishment of another national antiwar organization was declared. On December 17, 1940, at New York's Hotel Lexington, Verne Marshall, editor of the Cedar Rapids Gazette, announced the formation of the No Foreign War Committee. Like most other isolationists, Marshall felt that the United States should build an impregnable defense. Indeed, he demanded that William S. Knutson of the Council of National Defense be given "complete responsibility and authority to act as he chose." In addition, Marshall expressed general isolationist opinion in favor- 


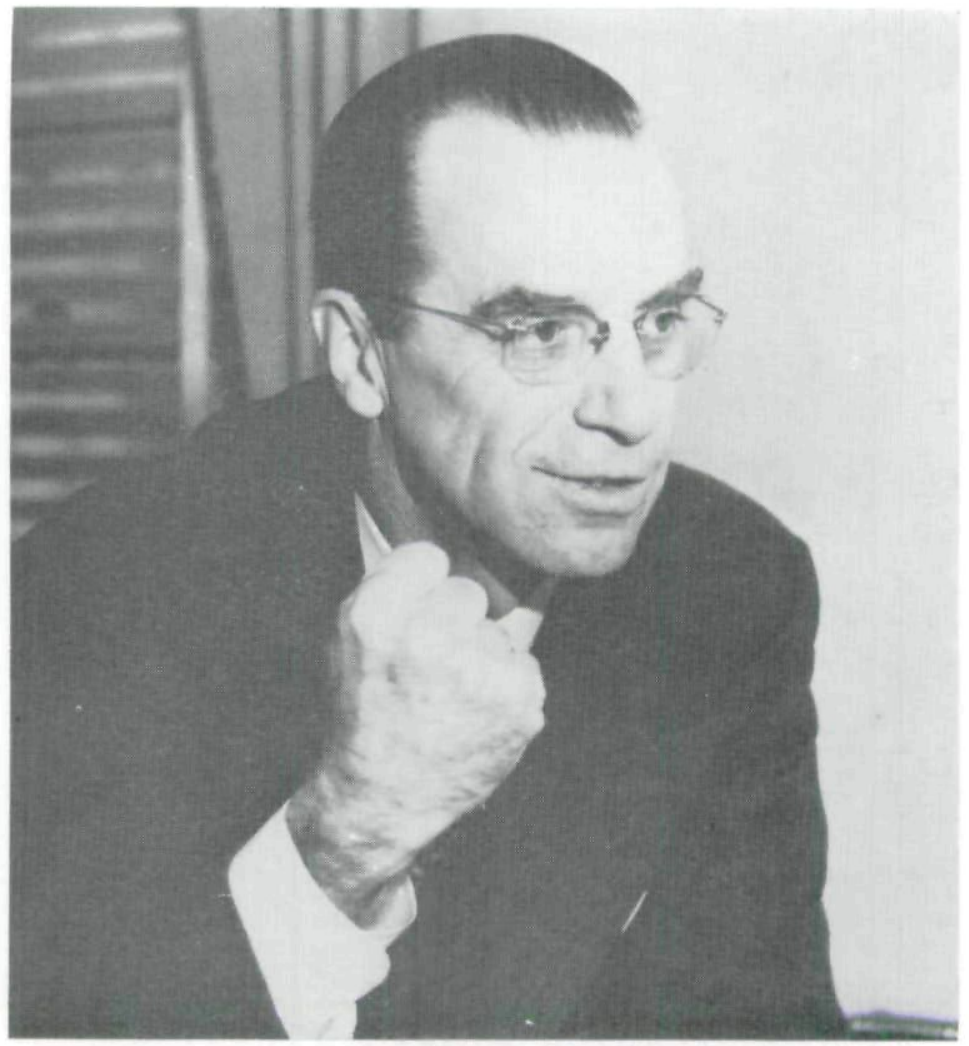

Courtesy of Des Moines Register and Tribune

Verne Marshall in 1940

ing American aid to Britain, within the limits of existing neutrality legislation, while opposing the sending of American convoys overseas. Some comments, however, were more pointed. He did not fear a German attack on Canada (then a current rumor) and regarded a possible Hitler attack on the United States even less likely; it was, he said, "purely poppycock." The Iowa editor also assailed William Allen White's Committee to Defend America by Aiding the Allies for spreading prowar propaganda, declaring, "Let no man accuse the No Foreign War Committee of being appeasers, fifth columnists, pro-Nazi, pro-British, pro-Fascist or of being anything save a group of determined pro-Americans. We have built this campaign of ours from the grassroots upward." 
Not only were fifteen senators and twenty-five representatives ready to speak on behalf of the new Committee, but the Roosevelt Administration, he said, would soon be besieged by newspaper ads, mass meetings, and posters. "We expect money to roll in faster than we can spend it," Marshall declared. ${ }^{1}$

Marshall himself was a character out of a Sinclair Lewis novel. Stockily built and wearing rimless spectacles, Marshall chewed cigars incessantly, punctuated his conversation with "damns" and "hells," and was fond of such epithets as "redblooded" and "two fisted." Cub reporter at age nineteen, and ambulance driver for the French army in 1916 at Verdun, Marshall inherited the editorship of the Cedar Rapids Gazette from his father in 1932. He had won a Pulitzer Prize for exposing a slot machine ring in Sioux City in 1935 , but a $\$ 700$ fee paid directly from the Gazette to the Special Prosecutor invalidated the convictions of the defendants. ${ }^{2}$ The editor's social views were less than enlightened. According to one account, Marshall, while driving through a Cedar Rapids slum, was asked by his daughter: "Papa, why do people have to live in such awful houses?" Marshall was not pleased with her observation. He thought that Iowa's offspring were having their minds polluted by the textbooks of Harold J. Rugg and the collectivist plotters of the Teacher's College of Columbia University. Rugg, a professor of education at Columbia, wrote a series of textbooks which had been under attack from the American Right for its "collectivist" bias. As a result of fiery editorials attacking Rugg's "radicalism," Marshall's name had spread far beyond the vast Iowa cornfields and in 1936 he was chosen to give the Americanization Address to the American Legion. ${ }^{3}$

${ }^{1}$ New York Times, December 18, 1940, p. 12.

${ }^{2}$ Current Biography, 1941, (New York: H. W. Wilson Co., 1942), p. 561. This source noted that Marshall's accusations had led to a grand jury indictment and the conviction of 31 state officials for graft. However, the Iowa Supreme Court declared that the convictions were invalidated, as the special prosecutor had secured a $\$ 700$ fee from the Gazette. While Marshall denied this, saying that the court had been "misled by defense counsel," the officials were released.

${ }^{3}$ Dale Kramer, "Verne Marshall of Iowa," New Republic, CIV (January 13, 1941), 50 . 
The other leaders of the No Foreign War Committee seemed to be capable individuals. Orland K. Armstrong, the director, usually went by the initials "O.K." A Missouri journalist, Armstrong had once headed the American Legion's Foreign Affairs Committee. According to the Manhattan (New York) tabloid, P.M., he had worked on the founding of the No Foreign War Committee while on the public relations staff of the Ford Motor Company at Dearborn, Michigan. ${ }^{4}$ The treasurer, Robert A. Lancaster, was a Harvardeducated investment banker with the firm of Winthrop and Marshall on Wall Street. Verne Marshall, Armstrong, and Lancaster had all fought in World War I-Lancaster as an ensign with the Atlantic Fleet and Armstrong as a flyer.

Although a board of directors was still to be announced, immediate financial backing seemed strong. There was fortyseven-year-old Douglas M. Stewart, ${ }^{5}$ for example, a Madison Avenue investment counsellor, who, in 1937, had bought The Commentator to serve as a journal promoting "free enterprise." In 1939 Stewart merged this with the failing Scribner's, renamed the new journal Scribner's Commentator, and dedicated this pocket-sized monthly to advocating isolationism. Scribner's Commentator adopted a strident tone, but as it was distributed to subscribers only, its audience was probably friendly to the cause.

Stewart's uncle was Jeremiah Milbank, whose interest ranged from his alma mater Yale, to the Baptist church, to his many corporation directorships. Milbank was reported to be ready to spend a million dollars to keep the nation out of war. Charles Shipman Payson also proved to be a financial "angel" of Scribner's Commentator. Married to a Whitney

${ }^{4}$ P.M., January 12,1941 , p. 12. P.M. was a New York tabloid started in 1940 by publisher Ralph Ingersoll, a former Time magazine executive. Financing came from Chicago merchant Marshall Field III. Highly polemical, the journal-in the words of the chief of its Washington Bureau, James A. Wechsler-applied "the epithet of 'traitor' to Americans" who refused to support Ingersoll's war effort and it would link "sincere isolationists and pacificists . . . indiscriminately with Bundists and Coughlinites ...." See James A. Wechsler, "The Life and Death of P.M.," Progressive, XIII (March, 1949), 11.

${ }^{5} \mathrm{He}$ was no relation to the Yale law student R. Douglas Stuart, Jr., who organized America First. 
heiress and a millionaire in his own right, the Harvard-educated Payson was prominent in steel and sugar refining. Working with Stewart and Payson, and responsible for day-by-day operations of the magazine was the thirty-four-year-old George Eggleston, described by one newspaper as a "rangy, friendly faced Westerner." Born in Oakland and a graduate of the University of California, Eggleston had been an editor for the old humor weekly, Life, and the Conde Nast publications before directing the new isolationist journal. A covert supporter was Merwin Kimball Hart, Utica insurance executive and president of the reactionary New York State Economic Council. Educated at St. Paul's School and Harvard College, Hart had made a twenty-year political odyssey from the Bull Moose party to the leadership of the American Union for Nationalist Spain. ${ }^{6}$

Colonel Charles A. Lindbergh was undoubtedly the most prominent man involved in the establishment of an independent organization to serve as an eastern counterpart to the Chicago-based America First Committee. The Lone Eagle met frequently with Stewart and Eggleston, who often came to the Lindbergh estate at Long Neck, Long Island for dinner. While at times Lindbergh wanted isolationists throughout the nation to back the America First Committee, at other times he thought that two regional associations might operate more effectively. ${ }^{7}$ Lindbergh reluctantly endorsed the appointment of Verne Marshall as chairman, affirming that his midwestern background and war record would make him an excellent rival to William Allen White. ${ }^{8}$ Within two days after the organization of the No Foreign War Committee was announced, Marshall noted that Lindbergh had promised to "do everything this committee wants me to do." Plans were made for a mass meeting in St. Louis, where the official campaign would

\footnotetext{
${ }^{6}$ For descriptions of Stewart and Eggleston, see P.M., January 12, 1940, p. 12, and The New York Times, December 31, 1940.

${ }^{7}$ For Lindberg's meetings with Stewart and Eggleston, see The Wartime Journals of Charles A. Lindbergh (New York: Harcourt Brace Jovanovich, 1970), 353, 358, 381, 394, 408, 409, 417, 421, and Passim. For his endorsement of two committees, see p. 427 (hereafter cited as Lindbergh Diaries).

${ }^{8}$ Ibid., December 15, 1940, p. 430.
} 
be launched. ${ }^{9}$

Pacifists were scheduled to play an important role in the new organization. O. K. Armstrong called an Emergency Peace Conference in Washington on October 21, 1940, with Colonel Lindbergh as featured speaker. Pacifists were there in abundance, led by lean, whitehaired Frederick J. Libby. Libby, born in Richmond, Maine, had been a Congregationalist minister, high school principal, and instructor at Phillips Exeter Academy before serving as a Quaker relief administrator during the Great War. As one of pacifism's most articulate historians notes, "He was a small man, built close to the bone as a Maine fence hugs the land, but his personality and energy were expansive." ${ }^{\prime 10}$ A confirmed believer in strict neutrality and total disarmament, Libby had been opposed to Roosevelt's interventionism since 1937. ${ }^{11}$

The Emergency Peace Conference tried to establish its own No Foreign War Campaign. Here both pacifist and nonpacifist opponents of New Deal foreign policy could cooperate. ${ }^{12}$ The lanky Quaker Libby soon won the confidence of the Lone Eagle. Lindbergh had met with Libby before the October rally in Washington; they soon became friends. ${ }^{13}$

In a letter written to R. Douglas Stuart, national director of America First, Lindbergh admitted that he differed with the pacifists on what he called "strong military forces for American Defense," but claimed that "the agitation for war and the trend towards it in this country have been so strong that I don't think we can afford to alienate any groups who

${ }^{9}$ New York Times, December 19, 1940.

${ }^{10}$ Charles Chatfield, For Peace and Justice: Pacifism in America, 1914-1941 (Knoxville: University of Tennessee Press, 1971), p. 148.

${ }^{11}$ Current Biography, 1949 (New York: H. W. Wilson Co., 1950), 355-7.

${ }^{12}$ Ruth Sarles, "A History of America First," undated manuscript, the Papers of the America First Committee, Hoover Library of War, Peace and Revolution, Stanford University (hereafter cited as AFC Papers).

${ }^{13}$ At their first meeting on March 2, 1940, Lindbergh recorded in his diary, "[Libby] is apparently rather a pacifist, but showed unusual understanding and intelligence (if one can apply the latter term to a pacifist).” See p. 320. By September Libby was a guest at Lindberg's Long Island Home, and in December, the flyer confided to his diary: "I like him more as I know him better." 
stand with us in opposition." ${ }^{14}$ Hence, with his genuine affection for Frederick Libby and his belief that all antiwar forces must coordinate their efforts, Lindbergh was particularly anxious that Armstrong merge his No Foreign War Campaign with Verne Marshall's No Foreign War Committee. The aviator was also insistent that Armstrong direct field organization for Marshall's new group. ${ }^{15}$ At first, efforts to gain pacifist backing seemed successful, for among those listed among the original backers of Marshall's committee in December, 1940, were Dr. Charles S. Boss, Jr., executive secretary of the Methodist World Peace Committee; Harold Chance, peace secretary of the American Friends Service Committee; and Mildred Scott Olmsted, executive secretary of the Women's International League for Peace and Freedom. ${ }^{16}$

Now at last, it would seem to the outside observer, antiwar leadership was at its peak. With America First already in action and based in Chicago, and with the new No Foreign War Committee of New York just swinging into action, the nation would surely be-in the eyes of anti-interventionistsmobilized against the oncoming tide of war propaganda. The New York group seemed to have the advantage of impassioned leadership, strong financial backing, and ties to pacifists, who were usually not affiliated with the National America First organization. ${ }^{17}$ Yet within two months after its birth on December 17, 1940, the No Foreign War Committee ceased major political activity and within four months it formally disbanded. What had happened?

Marshall's strong personality was partly responsible for the Committee's demise. Far too volatile to be effective, the

${ }^{14}$ Sarles, 101-2.

${ }^{15}$ Lindbergh Diaries, December 15, 1940, 420.

${ }^{16}$ New York Herald Tribune, December 23, 1940.

${ }^{17}$ The two pacifists on the National Committee of America First, Albert W. Palmer, president of Chicago Theological Seminary, and Oswald Garrison Villard, former owner of The Nation, soon resigned. See Wayne S. Cole, America First: The Battle Against Intervention, 1940-1941 (Madison: University of Wisconsin Press, 1953), p. 90. The original public announcement of the America First Committee had as its first plank that "The United States must build an impregnable defense for America" and as its second, "No foreign power, nor group of powers, can successfully attack a prepared America." Cole, 15. 
prairie journalist was no man to lead a mass movement. His tone was always shrill. He felt that the people of the United States were victims of a "dark conspiracy," similar to the supposed machinations of the Wilson Administration with Lord Balfour and Marshall Joffre in 1917. Marshall was convinced that Americans were again "being played for suckers"18

His penchant for exposes was also a factor in the committee's failure. In an editorial published in his Cedar Rapids Gazette, Marshall claimed that the European war would not have occurred had it not been for "unwritten" United States' commitments. Warning Roosevelt not to belittle his action committee, Marshall announced that if attacks on him continued, his organization might release a document detailing the "conspiracies" and "deceptions" which had forced nations into war. He wrote:

There are numerous individuals who can swear to the solemn truth of that solemn charge. To be sure, some of them are in prison, particularly in France and Poland. At least one king, or former king, knows the truth about the causes and inspiration of this ancient war and its two resumptions in the last quarter century. He, also, will speak the truth.

The document, he further maintained, showed how people were kept in "turmoil, fear, and servitude, even in some countries which erroneously are called democracies." After all, it was prepared in England by a man whose "integrity and deadly accuracy were unquestionable." 19

Marshall continually stressed the devious plots of the interventionists to wreck his efforts. He wrote in his Iowa paper:

Slimily, sneakingly, in dark corners, in sordid centers of un-Americanism, in certain places of great power, there proceed at this moment the schemings of men who would wreck the No Foreign War Committee. ${ }^{20}$

Marshall soon put a provision in his will which authorized

${ }^{18}$ New York Times, December 19, 1940.

${ }^{19} \mathrm{Ibid}$., December 26, 1940, p. 20. This charge of tacit American support was repeated later by isolationist historians. See in particular Charles C. Tansill, Back Door to War (Chicago: Henry Regnery Co., 1952 ), pp. 554-557, and Tansill's essay, "The United States and the Road to War in Europe," in Harry Elmer Barnes, ed., Perpetual Peace for Perpetual War (Caldwell, Idaho: Caxton Printers, 1953), pp. 167171.

${ }^{20}$ Ibid. 
the use of any part of his estate "that might be needed to finance investigation and fix the responsibility for any unnatural circumstance which might affect the death, injury or disappearance of Marshall, any members of his family or household, or his associates in the No Foreign War Committee." He also claimed that, in his strong box in Cedar Rapids, there was "special information" that would facilitate such an investigation. Yet, unless there was an "untoward incident," he would keep this incriminatory information to himself. ${ }^{21}$

A man like Marshall was bound to provoke opposition. According to the hostile New York P.M., Marshall had said, "I don't care who wins the war," and, "If Hitler comes to the U.S.A. I'll get myself back to Iowa, get on a piece of land, and stay there." ${ }^{22}$

To Marshall's own backers, probably the most embarrassing spectacle came during a radio debate on January 13, 1941. The America Town Meeting of the Air sponsored a discussion on the topic: "Is a Hitler Defeat Essential to the United States?" Marshall was pitted against Wall Street lawyer Dean Acheson. In his opening remarks Marshall referred to Acheson as "a gentleman and a scholar" who might or might not know what war meant. He then went on to say that he himself was "just a plain American." This comment met with audience cries of "No, No," to which Marshall replied, "So one says 'No' when I say I am an American. Let him come up here and say that here on this platform. I am twenty pounds underweight but I don't care how much he weighs." ${ }^{23}$ The stunned audience, suddenly turned silent, heard Marshall continue. His great-grandfather had fought along side Washington, his grandfather with Lincoln, and he himself had enlisted with the French before America had entered World War I. After noting that Hitler would assure freedom in Europe, he turned upon the moderator, accusing him of planting hostile people in the audience. Those named

${ }^{21}$ New York Times, December 28, 1940, p. 3.

${ }^{22}$ P.M., January 12, 1941. Marshall threatened a libel suit against this newspaper unless they retracted an article which appeared on

December $22,1940$. See New York Times, December 28,1940, p. 3.
${ }^{23}$ New York Times, January 10, 1941, p. 10. 
included Socialist leader Norman Thomas, Frederick J. Libby (at that point totally disenchanted by anything Marshall was connected with), and Dr. Frank Kingdon, president of Newark University and an interventionist. Both Thomas and Libby opposed military involvement but did not want their cause to be marred by Marshall's antics.

Marshall had reason to be wary, for during the question and answer period the prominent New York lawyer Morris Ernst asked Marshall to identify his financial backers. Marshall apparently took offense at this remark; he responded:

Anybody, any time, even Mr. Morris Ernst ... . can come

to our headquarters and read the list of contributors and the names and addresses of every real American who is willing to keep his country out of war. He can always have them, Mr. Morris Ernst. ${ }^{24}$

Ernst took Marshall at his word. Following the Iowa editor backstage after the broadcast, he requested an appointment at the No Foreign War Committee headquarters to look at the material. This time Marshall replied that he had not made an open offer; rather he would make the list public "at the proper time to the proper Americans." ${ }^{25}$

Marshall's supposed backers showed less than enthusiasm over his performance on Town Meeting. Almost immediately afterwards some were claiming that the Iowa editor had not been honest when he listed them as full-fledged members, or in some cases, as future directors. ${ }^{26}$ Of those that remained faithful, half were people whose regional reputation and influence might be considered somewhat limited. Men such as the president of the Kansas City Power and Light Company and the president of Coe College were not widely known or recognized. Aside from the pacifist leader Mildred Scott Olmsted, probably known only to America's peace circle, Senator

${ }^{24}$ Ibid.

${ }^{25}$ Ibid.

${ }^{26}$ For example, Archibald Roosevelt was cited by Marshall on December 22 as an endorser of the Committee. When the son of Theodore Roosevelt was contacted at his home in Cold Harbor, Long Island, he said that he had only endorsed a NFWC advertisement which was to appear in fifty newspapers. See New York Times, December 23, 1940. Dr. Charles S. Boss, Jr., the Methodist peace executive, soon told Religious News Service that Marshall had used his name without his consent. See unidentified clipping dated January 18, 1941, in AFC Papers. 
Rush Dew Holt of West Virginia alone had a national reputation. But given Holt's past flirtation with Father Coughlin's National Union for Social Justice, ${ }^{27}$ this reputation, in some eyes, would be less than positive. ${ }^{28}$

Marshall felt forced to reorganize the Committee on January 14, 1941 because of its image of internal turbulence; the new directors, however, were less than eminent personages. Two weeks earlier he had announced: "First in my consideration [of directors] is Mrs. Helen D. Longstreet of Savannah Beach, Georgia." Mrs. Longstreet, the widow of a Confederate general, was eighty-two years old, and national organizer of an obscure group called the Defenders of the Republic. The other directors listed included Charles Buddington Kelland, of Phoenix, author of boy's adventure stories and prominent Republican national committeeman; Major Frank K. Hahn of Cedar Rapids; Dr. Harry M. Gage; Don Barnes, a Cedar Rapids attorney; Bronson Bachelor, a Manhattan public relations counselor who served as publicity director for the Red Cross during World War I; and Mark M. Jones, president of the Akron Belting Company and member of the Committee on Economic Policy of the National Association of Manufacturers. Marshall said that Bachelor and Jones served as aid in the Committee's reorganization. ${ }^{29}$

Yet even these new leaders of the infant No Foreign War Committee gave reluctant support, and several withdrew support entirely. Kelland, while voicing his opposition to America being "hustled into war abroad," denied that he had given the Committee permission to use his name as a backer. ${ }^{30}$

\footnotetext{
${ }^{27}$ Father Coughlin's organization, founded in 1934, had served as a pressure group to back the radio priest's program of isolationism, remonetization of silver, and varied populist reforms. Holt was the keynoter for the group's national meeting in 1936.

${ }^{28}$ Other backers listed in Marshall's initial announcement of December 22 included Harold Chance, peace secretary of the American Friends Service Committee; Harry W. Colmery of Topeka, Kansas, former national commander of the American Legion; Dr. Harry M. Gage, president of Coe College in Cedar Rapids; and John F. Porter, president of the Kansas City Power and Light Company. Porter soon withdrew permission to use his name. New York Times, December 24, 1940, p. 7.

${ }^{29}$ New York Times, January 15, 1941.

${ }^{30}$ New York Herald Tribune, January 16, 1941.
} 
The mayor of Cedar Rapids resigned as a director with the explanation: "I signed the articles of incorporation before I was aware of the true nature of the Committee." ${ }^{31}$

Marshall and his New York backers were not on good terms with the America First organization, the foremost isolationist group in the nation at that time. Marshall, Douglas M. Stewart, Eggleston, and Hart accused the America First leaders of being "New Deal inspired," setting up a smokescreen designed to grab the nation's antiwar leadership and then dissipate it. America First, they contended, was headed by the inexperienced law student from Yale, R. Douglas Stuart, Jr., a man who ran an inefficient central office that was incapable even of answering its own correspondence. The America First Committee, inferred the Marshall forces, was also unable to secure the cooperation of pacifists and church groups, made the grave error of placing a Jew on its National Committee, and had working in its very office as director of organization one Robert L. Bliss, a man who had been in charge of promotion for the internationalist tabloid P.M. ${ }^{32}$ The opinion of this writer is that the charges leveled against the America First forces by Marshall and his backers were unfair and, in some cases, irrelevant. Robert E. Wood, national chairman of America First and chairman of the board of Sears, Roebuck had backed Roosevelt in 1932 and 1936, and had applauded such New Deal measures as social security and public housing. However, he became disenchanted by FDR's anti-business rhetoric and voted for Wendell Willkie in $1940 .^{33}$ R. Douglas Stuart, Jr., national director of America First, told P.M. that he might vote for Roosevelt and he believed in much of his domestic program; however he, like

${ }^{31}$ New York Post, January 16, 1941.

${ }^{32}$ R. D. Stuart, Jr, to R. E. Wood, December 8, 1940, AFC Papers; R. D. Stuart, Jr. to J. T. Flynn, December 2, 1940, the Papers of John T. Flynn, University of Oregon; memorandum of Harry Schnibbe to J. T. Flynn, enclosed with letter dated April 14, 1942, Flynn Papers (hereinafter cited as Schnibbe Memorandum), Sarles, P. 103.

${ }^{33}$ General Wood interview, Columbia University Oral History Project, 1960. See also "General Robert E. Wood, President," Fortune, XVII (May, 1938), 88-90. 
General Wood, ended up in the GOP camp. ${ }^{34}$

The No Foreign War Committee's accusation regarding pacifist groups has, in retrospect, little credibility. R. Douglas Stuart, Jr., who had represented America First at Armstrong's Emergency Peace Conference on October 21, 1940, supported the projected coordination between pacifists and non-pacifists, a dream of Frederick J. Libby since the war began. ${ }^{35}$ Even the crusty isolationist diplomat, William R. Castle, gave his approval, declaring, however, "It does not bother me if a man is a pacifist but it bothers me a lot if he is not a real American," ${ }^{36}$ but when it soon became obvious that Armstrong was far less interested in cooperation among existing groups than in setting up a new national organization, both Libby and Stuart balked.

Libby confided to Lindbergh that he could not possibly cooperate with any group established by Verne Marshall and persuaded Lindbergh, along with Armstrong, to work toward a loosely defined cooperation between pacifists and other noninterventionists. ${ }^{37}$ Next, he met with R. Douglas Stuart on December 2 and agreed to work informally with America First. Sidney Hertzberg, the pacifist and socialist who would serve as liaison, cried out jubilantly, "We have cut the Gordian knot" which had ensnared so much anti-war planning. ${ }^{38}$ Libby's National Council for the Prevention of War gave much aid to America First, including the loan of key researchers to staff the America First Office in Washington and New York. ${ }^{39}$

The issue of Jewish participation also separated the groups. For a brief time in the fall of 1940, Lessing Rosenwald, former board chairman of Sears, Roebuck, served on the national committee of America First. Resigning because of the anti-Semitic Henry Ford on the committee, Rosenwald still claimed allegiance to the principles of the organization. ${ }^{40}$

${ }^{34}$ P.M., October 4, 1940; Cole, p. 169.

${ }^{35}$ Sarles, pp. 100-101.

${ }^{36}$ Schnibbe Memorandum.

${ }^{37}$ Lindbergh Diaries, December 16, 1940, p. 430.

${ }^{38}$ Schnibbe Memorandum.

${ }^{39}$ Cole, pp. 89-90.

${ }^{40}$ Ibid., p. 133; Sarles, p. 124; Lessing Rosenwald to R. Douglas Stuart, Jr., December 3, 1940, AFC Papers. 
While some America First leaders, such as William R. Castle, made anti-Semitic remarks in private, America First welcomed Jews as members and tried to get other prominent Jews to serve on the national committee. Marshall was accused, even by fellow isolationists, of openly expressing anti-Semitism. He had supposedly claimed that the Jews were the power behind William Allen White's Committee to Defend America by Aiding the Allies. ${ }^{41}$ Marshall's attitude provoked criticism and opposition from men with as widely diverse political orientations as Norman Thomas, a socialist, and Herbert Hoover, the former Republican President. The No Foreign War Committee, led by Marshall, was ultimately unable to obtain support from the America First organization. ${ }^{42}$

Before assuming the leadership of the No Foreign War Committee himself, Marshall had tried to get one of the original members of America First's executive committee to head the group. He sought out General Hanford MacNider of Mason City, Iowa, the most decorated man in World War I after General Pershing. MacNider had been a past National Commander of the American Legion, Coolidge's Assistant Secretary of War, and Hoover's Minister to Canada. A favorite son at the Republican convention of 1940, his name had been placed in nomination for the presidency by Marshall himself. MacNider declined the leadership role. He pleaded insufficient time as the reason, but the America First organization later learned that MacNider considered the Marshall forces too reactionary.

Marshall had apparently never been a popular choice to head a national antiwar body. Less than a week before the formation of the No Foreign War Committee was announced, MacNider had arranged a unity meeting between General Wood of America First and Marshall at New York's Waldorf Astoria. Nothing was accomplished. Marshall simply repeated the charge that the General was a tool of the New Deal, and Wood left with the firm conviction that Marshall was reaching

${ }^{41}$ W. R. Castle to M. K. Hart, December 28, 1940, reprinted in P.M., March 20, 1941.

${ }^{42}$ New York Times, January 12, 1941, p. 14; January 6, 1941, p. 8; Sarles, p. 103; Schnibbe Memorandum. 
a state of nervous exhaustion. As America First's official history notes, "The meeting terminated with the two factions severing negotiations completely." ${ }^{33}$

It was only a matter of time before the most prominent backer of the No Foreign War Committee, Charles A. Lindbergh, withdrew his support too. His initial endorsement had been somewhat reluctant in the first place, for as he told Jeremiah Milbank, a prominent New York financier and heavy contributor to America First, he had qualms about Marshall's "nervous condition" and, "there is something about his attitude on life that disturbs me." Marshall was fishing for his blessing. The Iowa editor, on the other hand, later claimed that he assumed leadership of the Committee with a great deal of personal reluctance. ${ }^{45}$ Whatever his true feelings may have been, Marshall continually told the press that Lindbergh had chosen him for the task. $^{46}$ As Marshall's fame turned to infamy, Lindbergh finally defined his relationship to the leader of the No Foreign War Committee. On January 16, 1941 he telegrammed the Associated Press from Huntington, Long Island, saying that while he had had frequent meetings with Marshall's backers before the Committee was formed, he found himself unable to support its methods and policies. He denied ever having been a member of the group, or having made a contribution, and said that he would not address the forthcoming rally in St. Louis. He wrote in his diary, "I disliked doing this, but could not stand for Marshall's references to me in his interview." ${ }^{\prime 4}$

O. K. Armstrong also withdrew support from the Committee. At a supper at Lindbergh's home on January 4, 1941, he and the Lone Eagle discussed the possibility of forming still another antiwar group, one which would sponsor mass meetings throughout the country. ${ }^{48}$ After a trip to New York in a

${ }^{43}$ Sarles, pp. 103-104.

${ }^{44}$ Lindbergh Diaries, December 12, 1940, p. 427.

${ }^{45} \mathrm{~V}$. Marshall to C. C. Tansill, April 11, 1951, Tansill Papers.

${ }^{46}$ New York Times, December 23, 1940 , p. 1.

${ }^{47}$ Ibid., January 17, 1941, p. 9; St. Louis Post-Dispatch, January 16, 1941; Lindbergh Diaries, January 16, 1941, p. 440.

${ }^{48}$ Lindbergh Diaries, January 4, 1941, p. 436. 
last ditch effort to wrest control of the Committee from Marshall, Armstrong submitted his resignation.

As if the defection of Lindbergh and Armstrong were not enough, the No Foreign War Committee could enlist few new prominent backers or contributors. True, James A. Reed, former Senator from Missouri and oldtime foe of the League of Nations, made an anti-interventionist statement under No Foreign War Committee auspices, and Senator Arthur Capper of Kansas made a CBS broadcast under the group's sponsorship. Senator Bennett Champ Clark of Missouri endorsed the Committee's efforts. ${ }^{49}$ There was a sponsoring committee of over two hundred people but few were prominent. Only one, the humorist Irvin S. Cobb of Santa Monica, California, was on the National Committee of America First. ${ }^{50}$

Contributions to the No Foreign War Committee came predominantly from Marshall's own Cedar Rapids Gazette, which paid $\$ 41,000$ to launch the initial advertisement of the Committee's activities and intentions. The Gazette was committed to pay up to $\$ 100,000$ of the Committee's expenses. ${ }^{51}$ Robert A. Lancaster, the NFWC treasurer, told the Rev. L. M. Birkhead, Director of the Friends of Democracy, that Marshall and the Gazette were the only large contributors, and maintained that most donors gave only from one to ten dollars. ${ }^{52}$

The crowning blow to Marshall's movement involved a secret Germany peace agenda which, as he confessed to readers of the Gazette, made him "mentally drunk." ${ }^{33}$ In October, 1940, Marshall had been called to New York by Samuel F. Pryor, Jr., a director of Pan American Airways and vice-chairman of the Republican National Committee, to aid in the Wendell Willkie campaign. After a week, Pryor took Marshall to the Scarsdale home of fifty-one-year-old William Rhodes Davis, an independent oil operator. Davis spent the evening telling Marshall of some conversations he had had

\footnotetext{
${ }^{49}$ See No Foreign War Committee brochures in New York Public Library.

${ }^{50}$ Mimeographed list of sponsors, "NFWC Folder," AFC Papers.

${ }^{51}$ New York Times December 23, 1940; December 31, 1940, p. 6.

${ }^{52}$ Ibid. January 11, 1941.

${ }^{53}$ Current Biography, 1941 (New York: H. W. Wilson Co., 1942), p. 561 .
} 
the previous year with Herman Goering, and gave Marshall permission to use these conversations in the Willkie campaign. ${ }^{54}$

A series of events and rumored events ensued concerning Davis' attempts to use certain connections in Washington and Germany (established largely through his business enterprises) to arrange a European settlement between the hostile countries. Verne Marshall backed Davis and inferred that the Roosevelt Administration had rejected him as a mediator and had thereby failed to support valuable peace negotiations. Later it was revealed in a United Press bulletin from Berlin, dated December 31, that the German Foreign Office denied all knowledge of Davis' peace plan. Marshall retorted, "It makes no difference what any press association reports from Berlin. I have seen the agenda of which I speak." ${ }^{55}$ Davis reciprocated, giving his support to Marshall and the No Foreign War Committee, only to withdraw it a week later. $\mathrm{He}$ also declared cautiously that in announcing the Nazi peace proposal he had acted as a loyal citizen who had used his contacts to keep his government informed. ${ }^{56}$

Marshall, feeling the sting of betrayal, later wrote that the Town Meeting of the Air debate had justifiably caused Davis, Lindbergh and most other important backers to disavow all affiliation with him. ${ }^{57}$ The New York Times soon reported that Lindbergh had been upset by Marshall's obsession with the Davis peace tales and felt that the Iowa editor was neglecting the organizational side of the Committee's campaign. ${ }^{58}$ As Lindbergh himself was a strong advocate of a negotiated peace, this was telling criticism.

All that followed was anti-climactic. Marshall still reached for the headlines, one day accusing the government of harboring secret plans to turn the nation into an armed camp, another day telling 1,500 people gathered at a Coughlinite rally

\footnotetext{
${ }^{54}$ V. Marshall to C. C. Tansill, April 11, 1951.

${ }^{55}$ New York Times, January 1, 1941, p. 1, 14.

${ }^{56} \mathrm{Ibid}$., For a recent provocative account of the Davis mission, see Ladislas Farago's The Game of the Foxes (New York: McKay, 1972).

${ }^{57}$ V. Marshall to C. C. Tansill, April 11, 1951, Tansill Papers.

${ }^{58}$ New York Times, January 12, 1941, p. 4.
} 
in Queens, New York, that threats could not prevent him from addressing an antiwar rally. ${ }^{59}$ On February 18 Marshall accused Secretary of Interior Harold Ickes of plotting to seize the Federal Communications System and imposing censorship upon the wire services. "I see Verne Marshall is running around again with his little toy balloon," Ickes retorted. Marshall "doesn't need a censor; he needs a nurse."

Thereafter, the Committee steadily lost ground, until on April 29 it was formally dissolved. Bequesting its mission to America First and kindred organizations, Marshall declared that the group was:

organized last December to provoke increased public discussion of the danger of this country's involvement in overseas conflicts for which the American people are in no way responsible and to meet the propaganda groups seeking that involvement. These purposes have been served. Those who have actively engaged in this work will now return to their private affairs. All obligations of the Committee have been met. ${ }^{61}$

Davis soon died of a heart attack, although Marshall later claimed, "there is reason to believe it resulted from other causes, violence being No. 1." ${ }^{\prime 2}$ Eggleston and Douglas M. Stewart continued to publish Scribner's Commentator from Lake Geneva, Wisconsin. Armstrong worked in Missouri as an America First organizer. Lindberg joined the National Committee of America First and became its most popular speaker. Marshall returned to Iowa to write occasionally for local newspapers.

The death of the No Foreign War Committee had few mourners. Most of its backers were strongly opposed to the domestic reforms of the previous ten years and found even the America First Committee- by no means a radical group - far too liberal. Although many Americans opposed Roosevelt's interventionism, isolationist leaders as respected as Lindbergh, as industrious as O. K. Armstrong and as wealthy as Charles Payson, briefly entrusted the fortunes of

${ }^{59}$ Ibid., January 8, 1941, p. 8; January 12, 1941, p. 14; January 13, 1941 , p. 5.

${ }^{60}$ Ibid., January 9, 1941.

${ }^{61}$ Ibid., April 30, 1941, p. 8.

${ }^{62}$ V. Marshall to C. C. Tansill, April 11, 1951, Tansill Papers. 
much of the antiwar movement to a relatively obscure midwestern newspaper editor whose volatile personality led to conflict with even his most enthusiastic backers. To expect the beloved pacifist Frederick J. Libby to cooperate for long with such a mercurial figure was the height of naiveté. To believe that the Administration's foreign policy could be stemmed by an archaic peace proposal emitting from Hermann Goering was equally ludicrous.

Verne Marshall, forever the journalist, saw the antiwar crusade in need of continual headlines. He would supply them. Every accusation against the interventionists had to have - he felt-overtones of conspiracy. A good reporter not only needs an "angle," but must always scoop the opposition. Hence Marshall's fight against the Roosevelt Administration's foreign policy was conducted in the same spirit as his battle against the Sioux City slot machine gang. The Cedar Rapids editor did not lack courage; he simply failed to make the distinction between bravery and audacity so essential to mass leadership.

Marshall, who died in March, 1965, was never again in the national spotlight. He continued to oppose much American intervention during the Cold War, writing his fellow Iowan, Herbert Hoover, in 1954 that "our foreign policy, if long continued, will pretty well wreck us, provided a socialistic domestic policy has not already done so." ${ }^{33}$ In newspaper columns for the Marion (Iowa) Sentinel, Marshall, like many other World War II isolationists, praised the non-intervention sentiments of Senator Robert A. Taft, attacked what he called the "Korean fiasco," was obsessed with Communist "subversion," and called for a more strident policy against Communist China. Yet at the same time, he supervised an American Field Service project to bring sixty-eight foreign high school students to study in Cedar Rapids schools. Said Marshall, seeing no conflict between such activity and his views on foreign policy, "I never was an isolationist. That was what the crack-pots and radicals said. I was a nationalist, I still

\footnotetext{
${ }^{63}$ Verne Marshall to Herbert Hoover, March 5, 1954, Herbert Hoover Papers, Herbert Hoover Presidential Library, West Branch, Iowa.
} 
am." 64

Like most opponents of American participation in World War II, Marshall had no regrets. He said in 1958:

If we would have stayed out of the war longer we could have made a better peace settlement. We wanted to stay out long enough to let Hitler take care of Stalin. Meanwhile we wanted to keep a strong Army and Navy to swing a big club after the Germans and Reds finished each other off. The way things have turned out proves we were right. ${ }^{65}$

While some scholars are now claiming that Marshall's argument possessed much cogency, ${ }^{66}$ the Roosevelt Administration was unwilling to risk a Hitler victory. Unfortunately, so long as Marshall's flamboyance held the spotlight, even his own most telling points remained obscure.

${ }^{64}$ Davenport Democrat Times, April 20, 1958. I am grateful to Mrs. Judith Gildner for sharing this source with me.

${ }^{65}$ Ibid.

${ }^{66}$ Bruce M. Russett, a Yale political scientist, claims that Hitler's Russian campaign, a failure by the end of 1941, could easily have led to the mutual exhaustion of both the Russian and German empires by 1945 had the United States not intervened. See No Clear and Present Danger: A Skeptical View of the U. S. Entry into World War II (New York: Harper and Row, 1972), pp. 27-31. 
Copyright of Annals of Iowa is the property of State of Iowa, by \& through the State Historical Society of Iowa and its content may not be copied or emailed to multiple sites or posted to a listserv without the copyright holder's express written permission. However, users may print, download, or email articles for individual use. 